\title{
Yaşlı Tip 2 Diyabetli Bireylerde Diyabet Yükünün İncelenmesi: Zonguldak İli Örneği
}

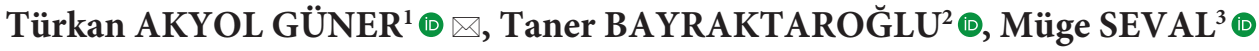 \\ ${ }^{1}$ Zonguldak Bülent Ecevit Üniversitesi, Sağlık Bilimleri Fakültesi Sosyal Hizmet Bölümü, Kozlu, Zonguldak, Türkiye \\ ${ }^{2}$ Zonguldak Bülent Ecevit Üniversitesi, Tıp Fakültesi, Endokrinoloji ve Metabolizma Hastalıkları Anabilim Dalı, Zonguldak, Türkiye \\ ${ }^{3}$ Zonguldak Bülent Ecevit Üniversitesi, Sağlık Bilimleri Fakültesi, Çocuk Sağlı̆̆ı ve Hastalıkları Hemşireliği Anabilim Dalı, Kozlu, Zonguldak, Türkiye
}

Bu makaleye yapılacak atıf: Akyol Güner T, Bayraktaroğlu T, Seval M. Yaşlı Tip 2 Diyabetli Bireylerde Diyabet Yükünün İncelenmesi: Zonguldak İli Örneği. Türk Diyab Obez 2020;2: 108-118.

\begin{abstract}
Amaç: Bu çalışma ile Zonguldak İli’nde yaşayan yaşlı tip 2 diyabetli bireylerde diyabet yükünün incelenmesi amaçlanmıştır.
\end{abstract}
Gereç ve Yöntemler: Tanımlayıcı-kesitsel tipte tasarlanan bu çalışma, Ocak 2020-Mart 2020 tarihleri arasında yapılmıştır. Çalışma için Zonguldak'ın toplam nüfusu baz alınmış (2019 yllı nüfusu 596.053 kişi) araştırma evrenini temsil edecek örneklem büyüklüğü \% 95 güven aralığı ve $\alpha=0.05$ için 384 kişi olarak belirlenmiştir. Çalışma, 65 yaş ve üzeri, tip 2 diyabeti olan, görme ve işitme sorunu olmayan, sözlü iletişim kurabilen, çalı̧̧maya katılmaya gönüllü, Standardize Mini Mental Test’ten 23 puan ve üzerinde alan 395 kişi ile tamamlanmıştır. Veriler, araştırmacılar tarafından literatür taranarak hazırlanan Tip 2 Diyabetli Tanılama Formu ve Yaşlılarda Diyabetin Yükü Ölçeği kullanılarak yüz yüze görüşme yöntemi ile toplanmıştır.

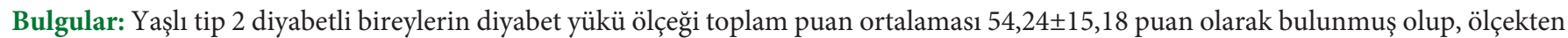
alınabilecek en düşük (18 puan) ve en yüksek (88 puan) puanlar dikkate alındığında katılımcıların diyabet yükünün orta düzeyde olduğu görülmüştür. Katılımcıların sosyodemografik özellikleri incelendiğinde; yaş ilerledikçe diyabet yükünün arttığı $(p<0,001)$, eğitim durumu yüksek olan, evli olan, eş ve çocukları ile yaşayan, sağlık ve gelir durumunu iyi olarak belirtenlerin diyabet yüklerinin daha az olduğu tespit edilmiştir ( $<<0,001)$. Katılımcıların diyabete ilişkin özelliklerine bakıldığında ise; diyabet tanı süreleri arttıkça, başka bir kronik hastalığı varsa, kullandıkları ilaç sayıları fazla ise ve diyabete bağlı komplikasyon gelişmişse diyabet yüklerinin daha fazla olduğu belirlenmiştir $(\mathrm{p}<0,001)$. Ayrıca ailesinde başka diyabetli olan, düzenli doktor kontrolüne gidemeyen, düzenli egzersiz yapamayan, ilaçlarını kendi alamayan ve diyabetle ilgili bilgi/eğitime gereksinim duyan katılımcıların da diyabet yüklerinin daha fazla olduğu belirlenmiştir $(\mathrm{p}<0,001)$.

Sonuç: Zonguldak ilinde yaşayan yaşlı tip 2 diyabetli bireylerin diyabet yüklerinin orta düzeyde olduğu saptanmıştır. Buna göre, yaşlı tip 2 diyabetli bireylerin ek hastalıklarının ve komplikasyonların kontrol altına alınması ile, düzenli doktor kontrolüne gitmelerinin ve düzenli egzersiz yapmalarının sağlanması ile yaşadıkları diyabet yüklerinin azaltılabileceği düşünülmektedir.

Anahtar Sözcükler: Yaşl, Tip 2 Diyabet, Diyabet yükü, Zonguldak ili

\section{Investigation of Diabetes Burden in Elderly Type 2 Diabetes Individuals: Example of Zonguldak Province}

\begin{abstract}
Aim: With this study, it was aimed to investigate the diabetes burden in elderly people with type 2 diabetes living in Zonguldak Province. Material and Methods: This descriptive-cross-sectional study was conducted between January 2020 and March 2020. For the study, based on the total population of Zonguldak (2019 population 596.053 people), the sample size to represent the research universe was determined as $95 \%$ confidence interval and 384 people for $\alpha=0.05$. The study was completed with 395 participants aged 65 and over, who had type 2 diabetes, had no vision and hearing problems, could communicate verbally, volunteer to participate in the study, who
\end{abstract}

ORCID: Türkan Akyol Güner / 0000-0003-0138-0669, Taner Bayraktaroğlu / 0000-0003-3159-6663, Müge Seval / 0000-0003-1917-285X 
received 23 points or more from the Standardized Mini Mental Test. The data were collected by using face-to-face interview method using Type 2 Diabetes Diagnostic Form prepared by the researchers by scanning the literature and Diabetes Burden Scale in the Elderly.

Results: The diabetes burden scale total score average of people with elderly type 2 diabetes was found to be $54.24 \pm 15.18$ points, and when the lowest (18 points) and the highest ( 88 points) scores were taken into consideration, the diabetes burden of the participants was moderate. When the socio-demographic characteristics of the participants are examined; It was found that the diabetes burden increases with age $(\mathrm{p}<0.001)$, the education level is high, the married people who live with their spouses and children, who have good health and income status have less diabetes burden $(\mathrm{p}<0.001)$. Looking at the characteristics of the participants regarding diabetes; It was determined that diabetes burden was higher when the duration of diagnosis of diabetes increased, if there was another chronic disease, the number of drugs used, and if complications related to diabetes developed $(\mathrm{p}<0.001)$. In addition, it was determined that the diabetic burden of the participants who had diabetes in their families, could not go to regular doctor control, could not exercise regularly, could not take their medications themselves and needed information / education related to diabetes ( $\mathrm{p}<0.001)$.

Conclusion: It was determined that the diabetic burden of the elderly type 2 diabetics living in Zonguldak province was moderate. It is thought that the burden of diabetes in elderly people with type 2 diabetes can be reduced by controlling their additional diseases and complications, ensuring regular physician control and regular exercise.

Key Words: Elderly, Type 2 Diabetes, Diabetes burden, Zonguldak province

\section{GİRIŞ}

Dünya Sağlık Örgütü (DSÖ) ile beraber birçok ülkede, 65 yaş ve üzeri bireyler yaşlı nüfus olarak kabul edilmektedir (1). Yaşam süresinin artması, son yüzyıl içerisinde kaydedilen en önemli gelişmelerden birisi olarak tanımlanmakta olup dünya nüfusu, doğum oranındaki azalma ve beklenen yaşam sürelerindeki artış sonucu her geçen yll giderek yaşlanmaktadır (2). Yapılan istatistiklere göre 2019 yılı itibari ile dünya üzerinde 703 milyon kişinin $(\% 9,1) 65$ yaş üstü olduğu bildirilmiş, bu sayının 2050 yılında iki katına çıkarak 1,5 milyar (\%15,9) olacağı öngörülmüştür (1). Ülkemizde de 65 yaş üstü nüfus oranı dünya verilerine benzer şekilde artış göstermiş, 2014 yllında 6 milyon (\%8) olan 65 yaş üzeri yaşlı nüfus son 5 yılda \%21,9 artarak 2019 yılında 7,5 milyon (\%9,1) kişiye ulaşmıştır (3).

Tüm dünyada özellikle gelişmekte olan ülkelerde yaşlı nüfusun artmasıyla birlikte, kronik hastalıklarda da artış gözlenmektedir. 65 yaş ve üstü bireylerin $\% 90$ 'ında bir, \%35'inde iki, \% 23'ünde üç, \% 15'inde ise dört ve daha fazla kronik hastalık görülmekte olup $(4,5)$, bu dönemde sık görülen kronik hastalıkların başında tip 2 diyabet hastalığ 1 gelmektedir (6). Tip 2 diyabet, tüm toplumda özellikle erişkin dönemde görülebilen, hastanın bağımsız yaşam sürdürmesini tehdit eden, kendisi ve ailesinin yaşamları üzerinde önemli etkisi olan, komplikasyonlarla seyreden, iyi tedavi edilmediğinde organ hasarına yol açabilen, yaşam kalitesini ciddi oranda azaltabilen, tedavi ve maliyeti oldukça yüksek sık görülen kronik bir hastalıktır $(6,7)$. Dünyada 2000 yılında 171 milyon olan diyabetli birey sayısı (8), 2018 yılında 463 milyona ulaşmış ve prevalansı \%9,3'e yükselmiştir. Bu artışın hız kesmeden süreceği, 2045 yılında ise 700 milyona yükseleceği öngörülmektedir (6). Türkiye'de de diyabet prevalansı dünya verileri ile benzerlik göstermekte olup 1998-2010 yılları arasında \%90 artış göstererek, prevalansını \%7,7'den \%13,7’ye çıkartmıştır (9). Tip 2 diyabetin ise toplam diyabet vakalarının \%90-95'ini oluşturduğu, yaşlı nüfusta görülme oranının \%32 civarında olduğu bildirilmiştir (6).

Diyabet hastalığı ile birey üzerinde oluşan fiziksel değişikliklerin yanında duygusal, ruhsal ve sosyal birtakım sorun ve çatışmalara da neden olmaktadır. Yaşanan endişe, depresyon, stres ve sosyal destek kaybı diyabet üzerinde olumsuz sonuçlar doğurarak hastalığı şiddetlendirmekte ve birey üzerine olan hastalık yükünü artırmaktadır (10). Ülkemizde yapılan Ulusal Hastalık Yükü Çalışması sonucuna göre, diyabet nedenli oluşan hastalık yükünde $\% 60$ artış gözlenerek yük oluşturan hastalıklar arasında ilk sıralara geldiği bildirilmektedir (11). Özellikle yaşlı diyabetliler hem yaşl1lığın getirdiği fizyolojik yük ile hem de diyabet tedavisi, komplikasyonları ve eşlik eden diğer kronik hastalıklardan dolayı diyabete ilişkin oluşan hastalık yükünü fazlaca hissetmekte ve baş etmeleri genç ya da erişkin diyabetlilere göre daha zor olmaktadır (12-14).

Yaşlılar arasında yaşanan diyabet yükü nedeniyle mortalite ve morbidite oranlarına önemli katkıda bulunacağı ve her yaşlıda farklı boyutlarda yaşanan bu diyabet yükü ile ilgili tedavi ve bakımın geliştirilmesinin gerekliliği bildirilmiştir (14-16). Bu sonuçlar ışığında, yaşlı diyabetli bireylere doğru tedavi ve bakımin uygulanabilmesi ve beraberinde hasta memnuniyetinin artırılabilmesi dolayısıyla sağlık harcamalarının da azaltılabilmesi için diyabet yükünü ölçmek ve ölçüm sonuçlarına yönelik tedavi ve bakımın planlanmasının yarar sağlayacağı düşünülmektedir. Bu nedenlerle bu çalışmada, Zonguldak İlinde yaşayan yaşlı tip 2 diyabetli bireylerde diyabet yükünün incelenmesi amaçlanmıştır. 


\section{GEREÇ ve YÖNTEMLER}

\section{Çalıșmanın Tasarımı ve Örneklem Seçimi}

Tanımlayıcı-kesitsel tipte tasarlanan bu çalışma, Ocak 2020Mart 2020 tarihleri arasında Zonguldak İli’nde gerçekleştirilmiştir. Çalışma için Zonguldak'ın toplam nüfusu baz alınarak örneklem sayısı hesaplanmıştır. Zonguldak 2019 yılı nüfusu 596.053 kişi olup (17), araştırma evrenini temsil edecek örneklem büyüklügü $\% 95$ güven aralığı ve $\alpha=0,05$ için 384 kişi olarak belirlenmiştir (18). Araştırmanın verileri, Zonguldak'ta faaliyet gösteren derneklere üye olan 65 yaş ve üzeri tip 2 diyabetli bireylerle yüz yüze görüşme yöntemi kullanılarak toplanmıştır. Çalışmaya başlamadan önce dernek başkanlarına çalışma ile ilgili bilgi verilmiş ve dernek üyelerine bildirilmesi istenmiştir. Ardından 65 yaş ve üzeri, tip 2 diyabet tanısı olan, görme ve işitme sorunu olmayan, sözlü iletişim kurabilen, çalışmaya katılmaya gönüllü katılımcılar ile veriler toplanmaya başlanmıştır. Çalışmanın başlangıcında katılımcıların mental durumlarının belirlenmesine yönelik Standardize Mini Mental Test (SMMT) uygulanmış $(19,20)$ ve bu testten 23 puan altında alan yaşlı diyabetliler çalışmaya dahil edilmemiştir. Verilerin toplanırken derneklerde toplantı amacıyla kullanılan odalar kullanılmış, bir anketin cevaplanma süresi ortalama 15-20 dakika sürmüştür.

\section{Veri Toplama Araçları}

Veriler, Tip 2 Diyabetli Tanılama Formu ve Yaşlılarda Diyabetin Yükü Ölçeği kullanılarak toplanmıştır.

Tip 2 Diyabetli Tanılama Formu: Araştırmacılar tarafindan literatür doğrultusunda hazırlanan bu formda $(21,22,23)$; yaş, cinsiyet, eğitim durumu, medeni durum, evde birlikte yaşadığı kişiler, başka bir kronik hastalığının olma durumu, kullanılan ilaçları ve diyabet hastalığına ilişkin bilgileri sorgulayan 17 soru bulunmaktadır.

Yaşlılarda Diyabetin Yüküi Ölçeği: 2003 yılında, Japonya'da, Araki ve Ito tarafından yaşlı ve diyabeti olan bireyler üzerinde diyabetin yükünü ölçmek amacıyla geliştirilmiş 23 maddelik likert tipi (0-4), 6 alt boyuttan oluşan bir araçtır (14). Türkçe geçerlilik ve güvenirliği 2012 yllında Usta ve Esen tarafından yapılan bu ölçeğin, Semptom Yükü (4 madde), Sosyal Yük (5 madde), Diyet Kısıtlamasından Kaynaklanan Yük (4 madde), Diyabet Hakkındaki Endişeden Kaynaklanan Yük (4 madde), Tedavi Memnuniyetsizliğine İlişkin Yük (3 madde) ve Oral Antidiyabetik ve İnsülinden Kaynaklanan Yük (3 madde)'ü sorgulayan 6 alt boyutu bulunmaktadır. Ölçeğin toplam puan aralığı 18-88'dir. Ölçek puanlarındaki artma o alandaki yükün artışına, puanlardaki azalma ise o alandaki yükün azlığına işaret etmektedir. Ölçeğin cronbach alpha kat sayısı 0.92 olarak bulunmuştur (24). Çalışmamızda ise ölçeğin cronbach alpha katsayısı 0.91 olarak bulunmuş ve güvenilir olduğu sonucuna ulaşılmıştır.

\section{İstatistiksel Analiz}

Veri analizlerinde SPSS 22.0 istatistik paket programı kullanılmıştır. Katılımcıların sosyodemografik özellikleri ve diyabete ilişkin özellikleri frekans ve yüzde şeklinde sunulmuştur. Ölçek ve alt boyut puanları minimum, maksimum, ortalama ve standart sapma değerleri ile gösterilmiştir. Sayısal verilerin normal dağılıma uygunluğu Shapiro Wilk testi ile değerlendirilmiștir. Verilerin normal dağılım gösterdiği belirlenmiştir. Bundan dolayı yaşlılarda diyabet yüküne ilişkin istatistiksel karşılaştırmalarda, parametrik testlerden olan iki bağımsız grubun karşılaştırılmasında $t$-testi, ikiden fazla bağımsız grubun karşılaştırılmasında ise, tek yönlü varyans analizinden (ANOVA) yararlanılmıştır. Tek yönlü varyans analizi sonucunda ortaya çıan farklılıkları belirlemek için de tamamlayıcı olarak kullanılan Post- Hoc testlerden olan LSD testi kullanılmıştır. Testlerde anlamlılık düzeyi $p<0.05$ olarak alınmıştır.

\section{Etik Konular}

Çalışmanın yapılabilmesi için Helsinki Deklarasyonu ilkeleri doğrultusunda, Zonguldak Bülent Ecevit Üniversitesi İnsan Araştırmaları Etik Kurulu'ndan 08.01.2020/710 tarih ve numaralı karar ile etik kurul oluru alınmıștır. Veriler toplanmaya başlanmadan dernek başkanlarından çalışmanın yapılabilmesi için yazılı izinleri alınmıştır. Ardından çalışmaya katılmaya gönüllü yaşlı diyabetli bireylere araştırmanın amacı hakkında bilgi verilip, kimliklerinin hiçbir şekilde açıklanmayacağı belirtilerek, bilgilendirilmiş gönüllü olurları sözlü ve yazılı olarak alınmıştır.

\section{BULGULAR}

Araştırmadaki yaşlı tip 2 diyabetli bireylerden 361 kişi (\%91,4) 65-74 yaş aralığında olup, 238 kişi $(\%$ 60,3) ise erkekti. Katılımcıların 158'i (\%40) ilkokul mezunu, 325’i $(\% 82,3)$ evli, 189 'u $(\% 47,8)$ evinde eş ve çocukları ile yaşamaktaydı. Ayrıca 285 kişi $(\% 72,2)$ orta düzey gelir durumuna sahip ve 282 kişi $(\% 71,4)$ kendi sağllklarının orta düzeyde olduğunu düşünmekteydi (Tablo 1).

Katılımcıların \%34,4'ünün diyabet tanı süresi 15 yıl ve üzerinde olup $\% 58,2$ 'sinin diyabet dişında başka bir kronik hastalığ 1 da vardı. Kullandığ ilaç sayısı üç ve üzeri 211 kişi $(\% 53,4)$ ve diyabete bağl herhangi bir komplikasyon gelişmemiş 203 kişi $(\% 51,4)$ saptandı. Katılımcıların \%62,5’inin ailesinde başka diyabetli birey vardı ve \%51,6'sı düzenli doktor kontrolüne gidememekte, \%81'i düzenli egzersiz yapmamakta ve \%87,1'i ilaçlarını kendisi alabilmekteydi. Ayrıca çalışmaya katılan 311 kişi $(\% 78,7)$ diyabetle ilgili 
bilgi veya eğitime gereksinim duyduklarını belirtmekteydi (Tablo 2).

Yaşlı tip 2 diyabetli bireylere ait diyabet yükü ölçeği puanlarının dağılımı Tablo 3'te yer almaktadır. Diyabet yükü ölçeği toplam puan ortalaması $54,24 \pm 15,18$ puan olarak bulunmuş olup, ölçekten alınabilecek en düşük (18 puan)

Tablo 1: Katılımciların Sosyodemografik Özelliklerinin Dağılımı.

\begin{tabular}{|c|c|c|}
\hline \multicolumn{2}{|c|}{ Sosyodemografik özellikler } & $\begin{array}{c}\text { Olgu Sayısı } \\
\text { n (\%) }\end{array}$ \\
\hline \multirow{2}{*}{ Yaş } & $65-74$ yıl aras1 & $361(91,4)$ \\
\hline & 75-84 yıl arası & $34(8,6)$ \\
\hline \multirow{2}{*}{ Cinsiyet } & Kadın & $157(39,7)$ \\
\hline & Erkek & $238(60,3)$ \\
\hline \multirow{4}{*}{ Eğitim Durumu } & İlkokul & $158(40,0)$ \\
\hline & Ortaokul & $78(19,7)$ \\
\hline & Lise & $96(24,3)$ \\
\hline & Üniversite & $63(15,9)$ \\
\hline \multirow{2}{*}{ Medeni Durum } & Evli & $325(82,3)$ \\
\hline & Dul & $70(17,7)$ \\
\hline \multirow{4}{*}{$\begin{array}{l}\text { Evde Birlikte } \\
\text { Yaşadığı Kişiler }\end{array}$} & Yalnız & $50(12,7)$ \\
\hline & Eş & $129(32,7)$ \\
\hline & Eş ve Çocuk & $189(47,8)$ \\
\hline & Diğer & $27(6,8)$ \\
\hline \multirow{3}{*}{ Gelir Durumu } & İyi & $70(17,7)$ \\
\hline & Orta & $285(72,2)$ \\
\hline & Kötü & $40(10,1)$ \\
\hline \multirow{3}{*}{ Sağlık Durumu } & İyi & $63(15,9)$ \\
\hline & Orta & $282(71,4)$ \\
\hline & Kötü & $50(12,7)$ \\
\hline
\end{tabular}

ve en yüksek (88 puan) puanlar dikkate alındığında hastaların diyabet yükünün orta düzeyde olduğu görülmektedir (Tablo 3).

Katılımcıların yaşına göre diyabet yüklerine bakıldığında hem ölçeğin toplam puan ortalamasında hem de bütün alt boyutlarında istatistiksel olarak anlamlı farklılık belirlen-

Tablo 2: Diyabete İlișkin Özelliklerin Dağılımı.

\begin{tabular}{|c|c|c|}
\hline Diyabete İlişkin Özellikler & & $\begin{array}{c}\text { Olgu Sayısı } \\
\text { n (\%) }\end{array}$ \\
\hline \multirow{4}{*}{ Diyabet Tanı Süresi } & $<5$ Yil & $56(14,2)$ \\
\hline & 6-10 Yil & $115(29,1)$ \\
\hline & 11-15 Y11 & $88(22,3)$ \\
\hline & 15 yil üzeri & $136(34,4)$ \\
\hline \multirow{2}{*}{$\begin{array}{l}\text { Başka Bir Kronik } \\
\text { Hastalığının Olma Durumu }\end{array}$} & Hayır & $165(41,8)$ \\
\hline & Evet & $230(58,2)$ \\
\hline \multirow{3}{*}{ Kullanılan İlaç Sayısı } & Bir & $128(32,4)$ \\
\hline & İki & $56(14,2)$ \\
\hline & Üç ve üzeri & $211(53,4)$ \\
\hline \multirow{2}{*}{$\begin{array}{l}\text { Komplikasyon Gelişme } \\
\text { Durumu }\end{array}$} & Gelişmedi & $203(51,4)$ \\
\hline & Gelişti & $192(48,6)$ \\
\hline \multirow{2}{*}{$\begin{array}{l}\text { Ailede Diyabetli } \\
\text { Birey Varlığı }\end{array}$} & Hayır & $148(37,5)$ \\
\hline & Evet & $247(62,5)$ \\
\hline \multirow{2}{*}{$\begin{array}{l}\text { Düzenli Doktor Kontrolüne } \\
\text { Gidebilme Durumu }\end{array}$} & Hayır & $204(51,6)$ \\
\hline & Evet & $191(48,4)$ \\
\hline \multirow{2}{*}{ Düzenli Egzersiz Yapma } & Hayır & $320(81,0)$ \\
\hline & Evet & $75(19,0)$ \\
\hline \multirow{2}{*}{ İlaçları Kendi Alma } & Hayır & $51(12,9)$ \\
\hline & Evet & $344(87,1)$ \\
\hline \multirow{2}{*}{$\begin{array}{l}\text { Diyabetle İlgili Bilgi/ } \\
\text { Eğitime Gereksinim }\end{array}$} & Hayır & $84(21,3)$ \\
\hline & Evet & $311(78,7)$ \\
\hline
\end{tabular}

Tablo 3: Katılımcıların Diyabet Yükü Ölçeği Puan Ortalamaları.

\begin{tabular}{|c|c|c|}
\hline Diyabet Yükü Alt Boyutları & $\begin{array}{c}\text { Puan } \\
\text { (Ort. } \pm \text { SS) }\end{array}$ & Min.-Mak. \\
\hline Semptom Yükü & $5,69 \pm 4,49$ & $0,00-15,00$ \\
\hline Sosyal Yük & $13,51 \pm 3,58$ & $5,00-20,00$ \\
\hline Diyet Kısıtlamasından Kaynaklanan Yük & $11,40 \pm 2,94$ & $8,00-16,00$ \\
\hline Diyabet Hakkındaki Endişeden Kaynaklanan Yük & $10,98 \pm 2,77$ & $8,00-16,00$ \\
\hline Tedavi Memnuniyetsizliğine İlişkin Yük & $4,18 \pm 1,33$ & $2,00-6,00$ \\
\hline Oral Antidiyabetik veya İnsülinden Kaynaklanan Yük & $8,49 \pm 2,07$ & $3,00-12,00$ \\
\hline Yaşlılarda Diyabet Yükü Ölçeği Toplam Puanı & $54,24 \pm 15,18$ & $26,00-84,00$ \\
\hline
\end{tabular}


miştir $(\mathrm{p}<0,001)$. Farklılıklar incelendiğinde ise yaş aralığ 1 75-84 yaş arasında olanların diyabet yüklerinin daha fazla olduğu bulunmuştur. Cinsiyetine göre diyabet yüklerine bakıldığında ise sadece semptom yükü alt boyutunda anlamlı farklılık tespit edilmiş olup, erkek katılımciların semptom yükü ölçek puanının kadın katılımcılara göre biraz daha yüksek olduğu belirlenmiştir( $\mathrm{p}=0,04)$, (Tablo $4 \mathrm{~A}$ ve $4 \mathrm{~B}$ ). Eğitim durumu ve medeni duruma göre kat1lımcıların diyabet yükü incelendiğinde ise, hem ölçeğin toplam puan ortalamasında hem de bütün alt boyutlarının puan ortalamalarında istatistiksel olarak anlamlı farklılıklar belirlenmiştir $(\mathrm{p}<0,001)$. Eğitim düzeyi yüksek ve evli olan katılımcıların diyabet yükü puanlarının daha düşük olduğu bulunmuştur (Tablo 4).

Evde birlikte yaşadığı kişilere, gelir durumuna ve sağlık durumuna göre katılımciların diyabet yükleri incelendiğinde ise, hem ölçeğin toplam puan ortalamasında hem de bütün alt boyutlarının puan ortalamalarında istatistiksel olarak anlamlı farklılık olduğu belirlenmiştir $(\mathrm{p}<0,001)$. Farklılıklar incelendiğinde ise eş ve çocukları ile yaşayan katılımcıların diyabet yüklerinin daha az, gelir durumu ile sağlık durumunu kötü olarak belirten katılımcıların diyabet yüklerinin daha fazla olduğu saptanmıştır (Tablo 4A ve 4B).

Katılımcıların diyabet tanı süresine, başka bir kronik hastalığa sahip olma durumuna, kullandığg ilaç sayısına ve komplikasyon gelişme durumuna göre diyabet yükleri incelendiğinde, hem ölçeğin toplam puan ortalamasında hem de bütün alt boyutlarının puan ortalamalarında istatistiksel olarak anlamlılık belirlenmiştir $(\mathrm{p}<0,001)$. Farklılıklar incelendiğinde ise, diyabet tanı süresi fazla olan, diyabet dışında başka bir kronik hastalığı olan, kullandıkları ilaç sayıları fazla olan ve diyabete bağlı herhangi bir komplikasyon gelişen yaşlı diyabetlilerin diyabet yükü puanlarının daha yüksek olduğu belirlenmiştir (Tablo 5A ve 5B).

Katılımcıların, düzenli doktor kontrolüne gidebilme, düzenli egzersiz yapabilme, ilaçlarını kendi alabilme, diyabetle ilgili bilgi/eğitime gereksinim duyma ve ailede başka diyabetli olma durumuna göre diyabet yükleri incelendiğinde ise, hem ölçeğin toplam puan ortalamasında hem de

Tablo 4A: Sosyodemografik Özelliklerine Göre Diyabet Yükü Ölçeği Puanlarının Dağılımı-1.

\begin{tabular}{|c|c|c|c|c|c|c|c|}
\hline $\begin{array}{l}\text { Sosyo- } \\
\text { demografik } \\
\text { Özellikler-1 }\end{array}$ & $\begin{array}{l}\text { Semptom } \\
\text { Yülkü } \\
\text { (Ort. } \pm S S)\end{array}$ & $\begin{array}{c}\text { Sosyal Yük } \\
\text { (Ort. } \pm \text { SS) }\end{array}$ & $\begin{array}{c}\text { Diyet Kısıt- } \\
\text { lamasından } \\
\text { Kaynaklanan } \\
\text { Yük } \\
\text { (Ort. } \pm \text { SS) }\end{array}$ & $\begin{array}{c}\text { Diyabet } \\
\text { Hakkındaki } \\
\text { Endişeden } \\
\text { Kaynak- } \\
\text { lanan Yük } \\
\text { (Ort. } \pm S S)\end{array}$ & $\begin{array}{c}\text { Tedavi Mem- } \\
\text { nuniyetsizli- } \\
\text { ğine İlişkin } \\
\text { Yük (Ort. } \pm S S \text { ) }\end{array}$ & $\begin{array}{c}\text { Oral } \\
\text { Andiyabetik } \\
\text { veya } \\
\text { İnsülinden } \\
\text { Kaynaklanan } \\
\text { Yük } \\
\text { (Ort. } \pm \text { SS) }\end{array}$ & $\begin{array}{l}\text { Yaşlılarda } \\
\text { Diyabet } \\
\text { Yüküi } \\
\text { Ölçeği } \\
\text { Toplam } \\
\text { Puanı } \\
\text { (Ort. } \pm \text { SS) }\end{array}$ \\
\hline \multicolumn{8}{|l|}{ Yaş } \\
\hline $65-74$ y1l & $5,20 \pm 4,27$ & $13,20 \pm 3,52$ & $11,20 \pm 2,94$ & $10,75 \pm 2,71$ & $4,08 \pm 1,33$ & $8,34 \pm 2,06$ & $52,77 \pm 14,72$ \\
\hline \multirow[t]{2}{*}{ 75-84 yıl } & $10,94 \pm 3,16$ & $16,74 \pm 2,51$ & $13,53 \pm 1,97$ & $13,41 \pm 2,12$ & $5,24 \pm 0,78$ & $10,00 \pm 1,41$ & $69,85 \pm 10,51$ \\
\hline & ${ }^{\mathrm{a}} \mathbf{p}<\mathbf{0 , 0 0 1}$ & ${ }^{\mathrm{a}} \mathbf{p}<\mathbf{0 , 0 0 1}$ & ${ }^{\mathrm{a}} \mathbf{p}<\mathbf{0 , 0 0 1}$ & ${ }^{\mathrm{a}} \mathbf{p}<\mathbf{0 , 0 0 1}$ & ${ }^{\mathrm{a}} \mathbf{p}<\mathbf{0 , 0 0 1}$ & ${ }^{\mathrm{a}} \mathbf{p}<\mathbf{0 , 0 0 1}$ & ${ }^{\mathrm{a}} \mathbf{p}<\mathbf{0 , 0 0 1}$ \\
\hline \multicolumn{8}{|l|}{ Cinsiyet } \\
\hline Kadın & $5,11 \pm 3,99$ & $13,90 \pm 3,06$ & $11,46 \pm 2,93$ & $11,06 \pm 2,58$ & $4,28 \pm 1,17$ & $8,71 \pm 2,24$ & $54,53 \pm 14,05$ \\
\hline \multirow[t]{2}{*}{ Erkek } & $6,08 \pm 4,76$ & $13,24 \pm 3,87$ & $11,36 \pm 2,94$ & $10,92 \pm 2,89$ & $4,11 \pm 1,43$ & $8,34 \pm 1,93$ & $54,05 \pm 15,90$ \\
\hline & ${ }^{\mathrm{a}} \mathrm{p}=0,04$ & ${ }^{\mathrm{a}} \mathrm{p}=0,07$ & ${ }^{\mathrm{a}} \mathrm{p}=0,75$ & ${ }^{\mathrm{a}} \mathrm{p}=0,63$ & ${ }^{\mathrm{a}} \mathrm{p}=0,21$ & ${ }^{\mathrm{a}} \mathrm{p}=0,08$ & ${ }^{\mathrm{a}} \mathrm{p}=0,76$ \\
\hline \multicolumn{8}{|c|}{ Eğitim Durumu } \\
\hline İlkokul (1) & $8,44 \pm 3,74$ & $15,77 \pm 2,66$ & $13,33 \pm 2,74$ & $12,97 \pm 2,65$ & $5,01 \pm 0,96$ & $9,72 \pm 1,64$ & $65,24 \pm 12,30$ \\
\hline Ortaokul (2) & $6,09 \pm 3,72$ & $14,47 \pm 2,64$ & $11,64 \pm 2,34$ & $10,77 \pm 1,86$ & $4,46 \pm 1,03$ & $9,00 \pm 1,53$ & $56,44 \pm 10,75$ \\
\hline Lise (3) & $4,22 \pm 3,89$ & $12,18 \pm 2,96$ & $9,68 \pm 1,93$ & $9,24 \pm 1,72$ & $3,71 \pm 1,05$ & $7,09 \pm 1,85$ & $46,11 \pm 9,79$ \\
\hline \multirow[t]{2}{*}{ Üniv. (4) } & $0,56 \pm 1,58$ & $8,67 \pm 0,95$ & $8,89 \pm 1,68$ & $8,89 \pm 1,68$ & $2,44 \pm 0,84$ & $6,89 \pm 1,54$ & $36,33 \pm 6,94$ \\
\hline & ${ }^{\mathrm{b}} \mathbf{p}<\mathbf{0 , 0 0 1}$ & ${ }^{\mathrm{b}} \mathbf{p}<\mathbf{0 , 0 0 1}$ & ${ }^{\mathrm{b}} \mathbf{p}<\mathbf{0 , 0 0 1}$ & ${ }^{\mathrm{b}} \mathbf{p}<\mathbf{0 , 0 0 1}$ & ${ }^{\mathrm{b}} \mathbf{p}<\mathbf{0 , 0 0 1}$ & ${ }^{b} \mathbf{p}<\mathbf{0 , 0 0 1}$ & ${ }^{\mathrm{b}} \mathbf{p}<\mathbf{0 , 0 0 1}$ \\
\hline \multirow{2}{*}{ Farklılıklar } & 1-2. 1-3. 1-4 & 1-2. 1-3. 1-4 & 1-2. 1-3. 1-4 & 1-2. 1-3. 1-4 & 1-2. 1-3. 1-4 & $1-2.1-3.1-4$ & $1-2.1-3.1-4$ \\
\hline & $2-3.2-4.3-4$ & $2-3.2-4.3-4$ & $2-3.2-4.3-4$ & 2-3. $2-4$ & 2-3. 2-4. 3-4 & $2-3.2-4$ & 2-3. 2-4. 3-4 \\
\hline
\end{tabular}

a: t-testi, b: Anova testi, (1): 1. Grup, (2): 2. Grup, (3): 3. Grup, (4): 4. Grup. 
Tablo 4B: Sosyodemografik Özelliklerine Göre Diyabet Yükü Ölçeği Puanlarının Dağılımı-2.

\begin{tabular}{|c|c|c|c|c|c|c|c|}
\hline $\begin{array}{l}\text { Sosyo- } \\
\text { demografik } \\
\text { Özellikler-2 }\end{array}$ & $\begin{array}{l}\text { Semptom } \\
\text { Yükü } \\
\text { (Ort. } \pm S S)\end{array}$ & $\begin{array}{c}\text { Sosyal Yük } \\
\text { (Ort. } \pm \text { SS) }\end{array}$ & $\begin{array}{c}\text { Diyet Kisıt- } \\
\text { lamasından } \\
\text { Kaynaklanan } \\
\text { Yük } \\
\text { (Ort. } \pm \text { SS) }\end{array}$ & $\begin{array}{c}\text { Diyabet } \\
\text { Hakkındaki } \\
\text { Endişeden } \\
\text { Kaynak- } \\
\text { lanan Yük } \\
\text { (Ort. } \pm S S)\end{array}$ & $\begin{array}{c}\text { Tedavi } \\
\text { Memnuni- } \\
\text { yetsizliğine } \\
\text { İlişkin Yük } \\
\text { (Ort. } \pm S S \text { ) }\end{array}$ & $\begin{array}{c}\text { Oral } \\
\text { Andiyabe- } \\
\text { tik veya } \\
\text { İnsülinden } \\
\text { Kaynak- } \\
\text { lanan Yük } \\
\text { (Ort. } \pm S S \text { ) }\end{array}$ & $\begin{array}{l}\text { Yaşlılarda } \\
\text { Diyabet } \\
\text { Yükü Ölçeği } \\
\text { Toplam } \\
\text { Puanı } \\
\text { (Ort. } \pm \text { SS) }\end{array}$ \\
\hline \multicolumn{8}{|c|}{ Medeni Durum } \\
\hline Evli & $4,74 \pm 4,25$ & $12,83 \pm 3,38$ & $10,50 \pm 2,36$ & $10,14 \pm 2,18$ & $3,81 \pm 1,17$ & $7,94 \pm 1,76$ & $49,95 \pm 12,88$ \\
\hline \multirow[t]{2}{*}{ Bekar/Dul } & $10,14 \pm 2,38$ & $16,63 \pm 2,75$ & $15,60 \pm 1,21$ & $14,86 \pm 1,72$ & $5,90 \pm 0,30$ & $11,04 \pm 1,32$ & $74,17 \pm 6,85$ \\
\hline & ${ }^{\mathrm{a}} \mathbf{p}<\mathbf{0 , 0 0 1}$ & ${ }^{\mathrm{a}} \mathbf{p}<\mathbf{0 , 0 0 1}$ & ${ }^{\mathrm{a}} \mathbf{p}<\mathbf{0 , 0 0 1}$ & ${ }^{\mathrm{a}} \mathbf{p}<\mathbf{0 , 0 0 1}$ & ${ }^{\mathrm{a}} \mathbf{p}<\mathbf{0 , 0 0 1}$ & ${ }^{\mathrm{a}} \mathbf{p}<\mathbf{0 , 0 0 1}$ & ${ }^{\mathrm{a}} \mathbf{p}<\mathbf{0 , 0 0 1}$ \\
\hline
\end{tabular}

Birlikte Yaşadığı Kişiler

\begin{tabular}{|c|c|c|c|c|c|c|c|}
\hline Yalnız (1) & $8,32 \pm 4,22$ & $15,58 \pm 4,11$ & $14,32 \pm 2,92$ & $13,84 \pm 2,85$ & $5,30 \pm 1,39$ & $10,42 \pm 2,13$ & $67,78 \pm 16,91$ \\
\hline Eş (2) & $7,74 \pm 4,15$ & $14,19 \pm 3,10$ & $11,82 \pm 1,74$ & $11,55 \pm 1,97$ & $4,44 \pm 0,92$ & $8,84 \pm 0,68$ & $58,58 \pm 10,15$ \\
\hline Eş ve Çocuk (3) & $2,86 \pm 2,98$ & $12,12 \pm 3,18$ & $9,68 \pm 2,32$ & $9,26 \pm 1,79$ & $3,44 \pm 1,11$ & $7,39 \pm 2,01$ & $44,76 \pm 11,14$ \\
\hline \multirow[t]{2}{*}{ Diğer (4) } & $10,89 \pm 1,48$ & $16,07 \pm 3,29$ & $16,00 \pm 0,00$ & $14,96 \pm 1,79$ & $6,00 \pm 0,00$ & $10,89 \pm 1,48$ & $74,81 \pm 2,94$ \\
\hline & ${ }^{\mathrm{b}} \mathbf{p}<\mathbf{0 , 0 0 1}$ & ${ }^{\mathrm{b}} \mathbf{p}<\mathbf{0 , 0 0 1}$ & ${ }^{\mathrm{b}} \mathbf{p}<\mathbf{0 , 0 0 1}$ & ${ }^{\mathrm{b}} \mathbf{p}<\mathbf{0 , 0 0 1}$ & ${ }^{\mathrm{b}} \mathbf{p}<\mathbf{0 , 0 0 1}$ & ${ }^{\mathrm{b}} \mathbf{p}<\mathbf{0 , 0 0 1}$ & ${ }^{\mathrm{b}} \mathbf{p}<\mathbf{0 , 0 0 1}$ \\
\hline \multirow{2}{*}{ Farklılıklar } & 1-3. 2-3. 1-4 & $1-2.1-3.2-3$ & 1-2. 1-3. 1-4 & 1-2. 1-3. 1-4 & 1-2. 1-3. 1-4 & 1-2. 1-3. 2-3 & $1-2.1-3.1-4$ \\
\hline & 2-4. 3-4 & 2-4. 3-4 & $2-3.2-4.3-4$ & 2-3. 2-4. 3-4 & 2-3. 2-4. 3-4 & 2-4. 3-4 & $2-3.2-4.3-4$ \\
\hline \multicolumn{8}{|l|}{ Gelir Durumu } \\
\hline İyi (1) & $0,50 \pm 1,51$ & $9,00 \pm 2,47$ & $9,10 \pm 1,71$ & $8,80 \pm 1,61$ & $2,40 \pm 0,81$ & $6,80 \pm 2,00$ & $36,60 \pm 7,73$ \\
\hline Orta (2) & $6,26 \pm 4,04$ & $14,02 \pm 2,79$ & $11,32 \pm 2,64$ & $10,81 \pm 2,29$ & $4,36 \pm 1,01$ & $8,62 \pm 1,83$ & $55,38 \pm 12,39$ \\
\hline \multirow[t]{2}{*}{ Kötü (3) } & $10,75 \pm 1,81$ & $17,75 \pm 2,31$ & $16,00 \pm 0,00$ & $16,00 \pm 0,00$ & $6,00 \pm 0,00$ & $10,50 \pm 1,52$ & $77,00 \pm 1,89$ \\
\hline & ${ }^{\mathrm{b}} \mathbf{p}<\mathbf{0 , 0 0 1}$ & ${ }^{\mathrm{b}} \mathbf{p}<\mathbf{0 , 0 0 1}$ & ${ }^{\mathrm{b}} \mathbf{p}<\mathbf{0 , 0 0 1}$ & ${ }^{\mathrm{b}} \mathbf{p}<\mathbf{0 , 0 0 1}$ & ${ }^{\mathrm{b}} \mathbf{p}<\mathbf{0 , 0 0 1}$ & ${ }^{\mathrm{b}} \mathbf{p}<\mathbf{0 , 0 0 1}$ & ${ }^{\mathrm{b}} \mathbf{p}<\mathbf{0 , 0 0 1}$ \\
\hline Farklılıklar & 3-1. 3-2. 2-1 & 3-1.3-2. 2-1 & 3-1.3-2. 2-1 & 3-1.3-2. 2-1 & 3-1. 3-2. 2-1 & 3-1.3-2. 2-1 & 3-1.3-2. 2-1 \\
\hline \multicolumn{8}{|l|}{ Sağlık Durumu } \\
\hline İyi (1) & $0,00 \pm 0,00$ & $8,33 \pm 1,50$ & $8,44 \pm 1,27$ & $8,44 \pm 1,27$ & $2,22 \pm 0,63$ & $6,22 \pm 1,76$ & $33,67 \pm 5,64$ \\
\hline Orta (2) & $5,95 \pm 3,79$ & $13,83 \pm 2,57$ & $11,24 \pm 2,45$ & $10,66 \pm 2,09$ & $4,29 \pm 0,97$ & $8,58 \pm 1,67$ & $54,56 \pm 10,73$ \\
\hline \multirow[t]{2}{*}{ Kötü (3) } & $11,40 \pm 2,08$ & $18,20 \pm 2,25$ & $16,00 \pm 0,00$ & $16,00 \pm 0,00$ & $6,00 \pm 0,00$ & $10,80 \pm 1,48$ & $78,40 \pm 3,30$ \\
\hline & ${ }^{\mathrm{b}} \mathbf{p}<\mathbf{0 , 0 0 1}$ & ${ }^{\mathrm{b}} \mathbf{p}<\mathbf{0 , 0 0 1}$ & ${ }^{\mathrm{b}} \mathbf{p}<\mathbf{0 , 0 0 1}$ & ${ }^{\mathrm{b}} \mathbf{p}<\mathbf{0 , 0 0 1}$ & ${ }^{\mathrm{b}} \mathbf{p}<\mathbf{0 , 0 0 1}$ & ${ }^{\mathrm{b}} \mathbf{p}<\mathbf{0 , 0 0 1}$ & ${ }^{\mathrm{b}} \mathbf{p}<\mathbf{0 , 0 0 1}$ \\
\hline Farklılıklar & 3-1. 3-2. 2-1 & 3-1. 3-2. 2-1 & 3-1. 3-2. 2-1 & 3-1. 3-2. 2-1 & 3-1. 3-2. 2-1 & 3-1. 3-2. 2-1 & $3-1.3-2.2-1$ \\
\hline
\end{tabular}

a: t-testi, ${ }^{\text {b: }}$ Anova testi, (1): 1. Grup, (2): 2. Grup, (3): 3. Grup, (4): 4. Grup.

bütün alt boyutlarının puan ortalamalarında istatistiksel olarak anlamlılık tespit edilmiştir $(\mathrm{p}<0,001)$. Farklılıklar incelendiğinde ise düzenli doktor kontrolüne gidemeyen, düzenli egzersiz yapamayan, ilaçlarını kendi alamayan ve diyabetle ilgili bilgi/eğitime gereksinim duyan ve ailesinde başka diyabetli olanların diyabet yükü puanlarının daha yüksek olduğu saptanmıștır (Tablo 5A ve 5B).

\section{TARTISSMA}

Tip 2 diabetes mellitus, tüm diyabetlilerin \%90-95'ini oluşturan küresel bir sağlık sorunudur (6). Yaş artışı ile birlikte görülme oranının artması, tedavi süresinin uzun, mortalite oranının yüksek ve beraberinde birçok komplikasyon riski bulunması sebebiyle bireyler üzerinde ciddi bir hastalık yükü oluşturmaktadır (25-27).

Yaşlı tip 2 diyabetli bireylerin diyabet yükünü ve etkileyen faktörleri incelediğimiz bu çalışmada, yaşlı diyabetli bireylerin diyabet yükü ölçeğinden aldıkları toplam puan ortalaması 54,24 15,18 puan olarak saptanmıştır. Ölçekten alınabilecek puanlar dikkate alındığında yaşlı tip 2 diyabetli bireylerin diyabet yüklerinin orta düzeyde olduğu tespit edilmiştir. Ovayolu ve ark. yaşlı hastalarda diyabetin zorluk- 
Tablo 5A: Diyabete İlişkin Özelliklerine Göre Diyabet Yükü Ölçeği Puanlarının Dağılımı-1.

\begin{tabular}{|c|c|c|c|c|c|c|c|}
\hline $\begin{array}{l}\text { Diyabete } \\
\text { İlişkin } \\
\text { Özellikler-1 }\end{array}$ & $\begin{array}{c}\text { Semp- } \\
\text { tom Yükü } \\
(\text { Ort. } \pm S S)\end{array}$ & $\begin{array}{l}\text { Sosyal Yük } \\
\text { (Ort. } \pm \text { SS })\end{array}$ & $\begin{array}{c}\text { Diyet Kisıt- } \\
\text { lamasından } \\
\text { Kaynak- } \\
\text { lanan Yük } \\
\text { (Ort. } \pm S S)\end{array}$ & $\begin{array}{c}\text { Diyabet } \\
\text { Hakkındaki } \\
\text { Endişeden } \\
\text { Kaynak- } \\
\text { lanan Yük } \\
\text { (Ort. } \pm \text { SS) }\end{array}$ & $\begin{array}{c}\text { Tedavi Mem- } \\
\text { nuniyetsizliği- } \\
\text { ne İlişkin Yük } \\
\text { (Ort. } \pm S S)\end{array}$ & 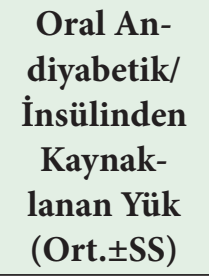 & $\begin{array}{l}\text { Yaşlılarda } \\
\text { Diyabet } \\
\text { Yüikü Öl- } \\
\text { çeği Top- } \\
\text { lam Puanı } \\
\text { (Ort. } \pm S S)\end{array}$ \\
\hline \multicolumn{8}{|l|}{ Diyabet Süresi } \\
\hline$<5$ Yil (1) & $0,00 \pm 0,00$ & $9,63 \pm 2,25$ & $8,88 \pm 1,55$ & $8,38 \pm 1,00$ & $2,25 \pm 0,67$ & $6,88 \pm 1,38$ & $36,00 \pm 5,71$ \\
\hline 6-10 Yil (2) & $3,02 \pm 3,08$ & $11,79 \pm 3,03$ & $9,10 \pm 1,69$ & $9,06 \pm 1,70$ & $3,51 \pm 0,86$ & $6,97 \pm 1,83$ & $43,45 \pm 9,15$ \\
\hline 11-15 Yil (3) & $6,50 \pm 2,53$ & $14,84 \pm 1,86$ & $11,77 \pm 2,13$ & $10,84 \pm 1,73$ & $4,65 \pm 0,79$ & $9,07 \pm 1,36$ & $57,67 \pm 7,79$ \\
\hline \multirow[t]{2}{*}{15 Yll Üzeri (4) } & $9,78 \pm 3,14$ & $15,69 \pm 3,26$ & $14,15 \pm 2,00$ & $13,76 \pm 1,95$ & $5,23 \pm 0,89$ & $10,05 \pm 1,39$ & $68,66 \pm 9,74$ \\
\hline & ${ }^{\mathrm{b}} \mathbf{p}<\mathbf{0 , 0 0 1}$ & ${ }^{b} p<0,001$ & ${ }^{\mathrm{b}} \mathbf{p}<\mathbf{0 , 0 0 1}$ & ${ }^{\mathrm{b}} \mathrm{p}<0,001$ & ${ }^{\mathrm{b}} \mathbf{p}<\mathbf{0 , 0 0 1}$ & ${ }^{\mathrm{b}} \mathbf{p}<\mathbf{0 , 0 0 1}$ & ${ }^{\mathrm{b}} \mathbf{p}<\mathbf{0 , 0 0 1}$ \\
\hline Farklılıklar & $\begin{array}{l}\text { 4-1. 4-2. 4-3 } \\
3-1.3-2.2-1\end{array}$ & $\begin{array}{l}\text { 4-1. 4-2. 4-3 } \\
3-1.3-2.2-1\end{array}$ & $\begin{array}{c}4-1.4-2.4-3 \\
3-1.3-2\end{array}$ & $\begin{array}{l}\text { 4-1. 4-2. 4-3 } \\
\text { 3-1. 3-2. 2-1 }\end{array}$ & $\begin{array}{l}\text { 4-1. 4-2. 4-3 } \\
3-1.3-2.2-1\end{array}$ & $\begin{array}{c}4-1.4-2.4-3 \\
3-1.3-2\end{array}$ & $\begin{array}{l}4-1.4-2.4-3 \\
3-1.3-2.2-1\end{array}$ \\
\hline \multicolumn{8}{|c|}{ Başka Kronik Hastalık } \\
\hline Hayır & $1,76 \pm 2,20$ & $10,55 \pm 2,74$ & $8,81 \pm 1,57$ & $8,53 \pm 1,24$ & $3,07 \pm 1,00$ & $6,72 \pm 1,61$ & $39,42 \pm 6,55$ \\
\hline \multirow[t]{2}{*}{ Evet } & $8,52 \pm 3,47$ & $15,63 \pm 2,42$ & $13,26 \pm 2,18$ & $12,74 \pm 2,15$ & $4,97 \pm 0,90$ & $9,75 \pm 1,28$ & $64,87 \pm 9,69$ \\
\hline & ${ }^{\mathrm{a}} \mathbf{p}<\mathbf{0 , 0 0 1}$ & ${ }^{\mathrm{a}} \mathbf{p}<\mathbf{0 , 0 0 1}$ & ${ }^{\mathrm{a}} \mathbf{p}<\mathbf{0 , 0 0 1}$ & ${ }^{\mathrm{a}} \mathbf{p}<\mathbf{0 , 0 0 1}$ & ${ }^{\mathrm{a}} \mathbf{p}<\mathbf{0 , 0 0 1}$ & ${ }^{\mathrm{a}} \mathbf{p}<0,001$ & ${ }^{\mathrm{a}} \mathbf{p}<\mathbf{0 , 0 0 1}$ \\
\hline \multicolumn{8}{|c|}{ Kullanılan İlaç Sayısı } \\
\hline $\operatorname{Bir}(1)$ & $1,29 \pm 1,91$ & $10,19 \pm 2,67$ & $8,82 \pm 1,57$ & $8,38 \pm 1,11$ & $2,80 \pm 0,98$ & $6,77 \pm 1,71$ & $38,24 \pm 6,57$ \\
\hline İki (2) & $3,52 \pm 2,57$ & $12,88 \pm 2,63$ & $9,73 \pm 1,90$ & $9,54 \pm 1,82$ & $4,00 \pm 0,00$ & $7,39 \pm 1,51$ & $47,05 \pm 6,93$ \\
\hline \multirow[t]{2}{*}{ Üç ve üzeri (3) } & $8,94 \pm 3,18$ & $15,69 \pm 2,52$ & $13,41 \pm 2,21$ & $12,94 \pm 2,06$ & $5,06 \pm 0,89$ & $9,82 \pm 1,31$ & $65,86 \pm 9,38$ \\
\hline & ${ }^{\mathrm{b}} \mathbf{p}<\mathbf{0 , 0 0 1}$ & ${ }^{\mathrm{b}} \mathbf{p}<0,001$ & ${ }^{\mathrm{b}} \mathbf{p}<0,001$ & ${ }^{\mathrm{b}} \mathrm{p}<0,001$ & ${ }^{\mathrm{b}} \mathbf{p}<0,001$ & ${ }^{\mathrm{b}} \mathbf{p}<0,001$ & ${ }^{b} p<0,001$ \\
\hline Farklılıklar & 3-1.3-2.2-1 & 3-1.3-2.2-1 & 3-1.3-2. 2-1 & 3-1. 3-2. 2-1 & 3-1.3-2.2-1 & 3-1.3-2. 2-1 & 3-1.3-2.2-1 \\
\hline \multicolumn{8}{|c|}{ Komplikasyon Durumu } \\
\hline Gelişmedi & $2,09 \pm 2,33$ & $11,50 \pm 2,98$ & $9,23 \pm 1,79$ & $8,90 \pm 1,60$ & $3,27 \pm 1,00$ & $7,15 \pm 1,70$ & $42,14 \pm 8,42$ \\
\hline \multirow[t]{2}{*}{ Gelişti } & $9,50 \pm 2,72$ & $15,63 \pm 2,87$ & $13,69 \pm 2,03$ & $13,18 \pm 1,91$ & $5,14 \pm 0,88$ & $9,90 \pm 1,35$ & $67,04 \pm 8,94$ \\
\hline & ${ }^{\mathrm{a}} \mathbf{p}<\mathbf{0 , 0 0 1}$ & ${ }^{\mathrm{a}} \mathbf{p}<\mathbf{0 , 0 0 1}$ & ${ }^{\mathrm{a}} \mathbf{p}<\mathbf{0 , 0 0 1}$ & ${ }^{\mathrm{a}} \mathbf{p}<\mathbf{0 , 0 0 1}$ & ${ }^{\mathrm{a}} \mathbf{p}<\mathbf{0 , 0 0 1}$ & ${ }^{\mathrm{a}} \mathbf{p}<0,001$ & ${ }^{\mathrm{a}} \mathbf{p}<\mathbf{0 , 0 0 1}$ \\
\hline
\end{tabular}

a: t-testi b: Anova testi (1): 1. Grup (2): 2. Grup (3): 3. Grup (4): 4. Grup

ları ve bunları etkileyen faktörleri belirlemek amacıyla yapmış oldukları çalışmada diyabet yükü ölçeği toplam puan ortalamasını $58,5 \pm 9,6$ puan olarak rapor etmişlerdir (21). Savsar’ın diyabetik ayağı olan yaşlı diyabetlilerin diyabet yüklerini belirlemek amacıyla yapmış olduğu çalışmada da ölçek toplam puan ortalaması $52 \pm 10,40$ puandır (22). Bu sonuçlarla karşılaştırdığımızda çalışmamızdaki yaşlı diyabetli bireylerin diyabet yükü ölçeğinden aldıkları toplam puan ortalamasının literatürdekine benzer şekilde orta düzeyde olduğu tespit edilmiştir.

Çalışmada katılımcılar DSÖ tarafından belirlenen yaşlılık dönemi yaş gruplarına göre sınıflandırılmıştır. Bu sınıflandırmada DSÖ, yaşlılığı 65-74 yaş arası genç yaşlı, 75-84 yaş arasını orta yaşlı ve 85 yaş üzerini ileri yaşlılık (ihtiyarlık) devri olarak bildirmektedir $(28,29)$. Çalışmada yaşlı tip 2 diyabetli bireylerin artan yaş ile birlikte diyabet yüklerinin de artmış olduğu belirlenmiştir. Yaşı 75 ve üzerindeki katılımcıların diyabet yükünün daha yüksek olduğu ve bu durumun istatistiksel olarak anlamlı olduğu tespit edilmiştir $(\mathrm{p}<0,001)$. Çalışmamıza benzer şekilde Araki ve Ito tarafından yapılan bir araştırmada yaş ile birlikte hastaların diyabet yüklerinin arttığı bildirilmiştir (14). Ovayolu ve ark. nın çalışmasında da benzer sonuç bulunmuştur (21). Yaşın ilerlemesi ile birlikte meydana gelen fiziksel sorunlar nedeni ile diyabetli bireylerin rollerini yerine getirmede daha fazla zorlanma yaşadıkları ve bu nedenle hastaların genç ya da yetişkin diyabetlilere göre diyabet yükünü daha fazla hissettikleri bildirilmektedir (30-33). 
Tablo 5B: Diyabete İlişkin Özelliklerine Göre Diyabet Yükü Ölçeği Puanlarının Dağılımı-2.

\begin{tabular}{|c|c|c|c|c|c|c|c|}
\hline $\begin{array}{l}\text { Diyabete } \\
\text { İlişkin } \\
\text { Özellikler-2 }\end{array}$ & $\begin{array}{l}\text { Semptom } \\
\text { Yükü } \\
\text { (Ort. } \pm S S)\end{array}$ & $\begin{array}{c}\text { Sosyal Yük } \\
\text { (Ort. } \pm \text { SS })\end{array}$ & $\begin{array}{c}\text { Diyet Kisıt- } \\
\text { lamasından } \\
\text { Kaynak- } \\
\text { lanan Yük } \\
\text { (Ort. } \pm S S)\end{array}$ & $\begin{array}{c}\text { Diyabet } \\
\text { Hakkındaki } \\
\text { Endişeden } \\
\text { Kaynak- } \\
\text { lanan Yük } \\
(\text { Ort. } \pm \text { SS) } \\
\end{array}$ & $\begin{array}{c}\text { Tedavi Memnu- } \\
\text { niyetsizliğine } \\
\text { Ilişsin Yük } \\
\text { (Ort. } \pm \text { SS) }\end{array}$ & $\begin{array}{c}\text { Oral } \\
\text { Andiyabetik/ } \\
\text { İnsülinden } \\
\text { Kaynak- } \\
\text { lanan Yük } \\
\text { (Ort. } \pm \text { SS) } \\
\end{array}$ & $\begin{array}{c}\text { Yaşlılarda } \\
\text { Diyabet Yüikü } \\
\text { Ölçeği } \\
\text { Toplam Puanı } \\
\text { (Ort. } \pm \text { SS) }\end{array}$ \\
\hline \multicolumn{8}{|c|}{ Ailede Başka Diyabetli Birey } \\
\hline Hayır & $4,16 \pm 4,48$ & $12,76 \pm 3,34$ & $10,13 \pm 1,89$ & $9,80 \pm 1,95$ & $3,48 \pm 1,26$ & $7,84 \pm 1,76$ & $48,17 \pm 12,53$ \\
\hline \multirow[t]{2}{*}{ Evet } & $6,62 \pm 4,24$ & $13,95 \pm 3,66$ & $12,16 \pm 3,18$ & $11,69 \pm 2,94$ & $4,60 \pm 1,20$ & $8,87 \pm 2,14$ & $57,88 \pm 15,48$ \\
\hline & ${ }^{\mathrm{a}} \mathbf{p}<\mathbf{0 , 0 0 1}$ & ${ }^{\mathrm{a}} \mathbf{p}<\mathbf{0 , 0 0 1}$ & ${ }^{\mathrm{a}} \mathbf{p}<\mathbf{0 , 0 0 1}$ & ${ }^{\mathrm{a}} \mathrm{p}<\mathbf{0 , 0 0 1}$ & ${ }^{\mathrm{a}} \mathbf{p}<\mathbf{0 , 0 0 1}$ & ${ }^{\mathrm{a}} \mathbf{p}<\mathbf{0 , 0 0 1}$ & ${ }^{\mathrm{a}} \mathbf{p}<\mathbf{0 , 0 0 1}$ \\
\hline \multicolumn{8}{|c|}{ Düzenli Doktor Kontrolü } \\
\hline Hayır & $7,64 \pm 4,32$ & $14,78 \pm 3,52$ & $13,15 \pm 2,64$ & $12,42 \pm 2,71$ & $4,75 \pm 1,38$ & $9,61 \pm 1,70$ & $62,35 \pm 14,20$ \\
\hline \multirow[t]{2}{*}{ Evet } & $3,62 \pm 3,66$ & $12,14 \pm 3,13$ & $9,53 \pm 1,92$ & $9,44 \pm 1,85$ & $3,56 \pm 0,95$ & $7,29 \pm 1,72$ & $45,58 \pm 10,78$ \\
\hline & ${ }^{\mathrm{a}} \mathbf{p}<\mathbf{0 , 0 0 1}$ & ${ }^{\mathrm{a}} \mathrm{p}<\mathbf{0 , 0 0 1}$ & ${ }^{\mathrm{a}} \mathbf{p}<\mathbf{0 , 0 0 1}$ & ${ }^{\mathrm{a}} \mathbf{p}<\mathbf{0 , 0 0 1}$ & ${ }^{\mathrm{a}} \mathbf{p}<\mathbf{0 , 0 0 1}$ & ${ }^{\mathrm{a}} \mathbf{p}<\mathbf{0 , 0 0 1}$ & ${ }^{\mathrm{a}} \mathbf{p}<\mathbf{0 , 0 0 1}$ \\
\hline \multicolumn{8}{|c|}{ Düzenli Egzersiz } \\
\hline Hayır & $6,76 \pm 4,28$ & $14,53 \pm 3,00$ & $12,02 \pm 2,84$ & $11,50 \pm 2,73$ & $4,48 \pm 1,21$ & $8,98 \pm 1,79$ & $58,27 \pm 13,54$ \\
\hline \multirow[t]{2}{*}{ Evet } & $1,16 \pm 1,63$ & $9,16 \pm 2,41$ & $8,75 \pm 1,57$ & $8,75 \pm 1,57$ & $2,88 \pm 1,00$ & $6,37 \pm 1,81$ & $37,07 \pm 8,16$ \\
\hline & ${ }^{\mathrm{a}} \mathbf{p}<\mathbf{0 , 0 0 1}$ & ${ }^{\mathrm{a}} \mathbf{p}<\mathbf{0 , 0 0 1}$ & ${ }^{\mathrm{a}} \mathbf{p}<\mathbf{0 , 0 0 1}$ & ${ }^{\mathrm{a}} \mathbf{p}<\mathbf{0 , 0 0 1}$ & ${ }^{\mathrm{a}} \mathbf{p}<\mathbf{0 , 0 0 1}$ & ${ }^{\mathrm{a}} \mathbf{p}<\mathbf{0 , 0 0 1}$ & ${ }^{\mathrm{a}} \mathbf{p}<\mathbf{0 , 0 0 1}$ \\
\hline \multicolumn{8}{|c|}{ İlaçları Kendi Alma } \\
\hline Hayır & $11,20 \pm 1,61$ & $15,86 \pm 3,74$ & $14,90 \pm 1,80$ & $14,35 \pm 1,99$ & $5,59 \pm 0,73$ & $10,00 \pm 1,43$ & $71,90 \pm 7,69$ \\
\hline \multirow[t]{2}{*}{ Evet } & $4,88 \pm 4,19$ & $13,16 \pm 3,43$ & $10,88 \pm 2,71$ & $10,48 \pm 2,51$ & $3,97 \pm 1,27$ & $8,26 \pm 2,05$ & $51,63 \pm 14,24$ \\
\hline & ${ }^{\mathrm{a}} \mathbf{p}<\mathbf{0 , 0 0 1}$ & ${ }^{\mathrm{a}} \mathbf{p}<\mathbf{0 , 0 0 1}$ & ${ }^{\mathrm{a}} \mathbf{p}<\mathbf{0 , 0 0 1}$ & ${ }^{\mathrm{a}} \mathbf{p}<\mathbf{0 , 0 0 1}$ & ${ }^{\mathrm{a}} \mathbf{p}<\mathbf{0 , 0 0 1}$ & ${ }^{\mathrm{a}} \mathbf{p}<\mathbf{0 , 0 0 1}$ & ${ }^{\mathrm{a}} \mathbf{p}<\mathbf{0 , 0 0 1}$ \\
\hline \multicolumn{8}{|c|}{ Diyabetle İlgili Bilgi/Eğitime Gereksinim } \\
\hline Hayır & $1,42 \pm 2,64$ & $10,42 \pm 3,47$ & $9,25 \pm 1,80$ & $9,00 \pm 1,74$ & $2,75 \pm 1,10$ & $7,00 \pm 1,93$ & $39,83 \pm 10,93$ \\
\hline \multirow[t]{2}{*}{ Evet } & $6,85 \pm 4,17$ & $14,34 \pm 3,13$ & $11,98 \pm 2,92$ & $11,51 \pm 2,75$ & $4,56 \pm 1,11$ & $8,89 \pm 1,92$ & $58,14 \pm 13,76$ \\
\hline & ${ }^{\mathrm{a}} \mathbf{p}<\mathbf{0 , 0 0 1}$ & ${ }^{\mathrm{a}} \mathbf{p}<\mathbf{0 , 0 0 1}$ & ${ }^{\mathrm{a}} \mathbf{p}<\mathbf{0 , 0 0 1}$ & ${ }^{\mathrm{a}} \mathbf{p}<\mathbf{0 , 0 0 1}$ & ${ }^{\mathrm{a}} \mathbf{p}<\mathbf{0 , 0 0 1}$ & ${ }^{\mathrm{a}} \mathbf{p}<\mathbf{0 , 0 0 1}$ & ${ }^{\mathrm{a}} \mathbf{p}<\mathbf{0 , 0 0 1}$ \\
\hline
\end{tabular}

a: t-testi 'b: Anova testi (1): 1. Grup (2): 2. Grup (3): 3. Grup (4): 4. Grup

Çalışmamıza katılan yaşlı tip 2 diyabetlilerden medeni durumunu evli olarak belirtip eş ve çocukları ile yaşayanların diyabet yüklerinin daha az olduğu ve bu farklılıkların istatistiksel olarak anlamlı oldukları belirlenmiştir $(\mathrm{p}<0,001)$. Çalışmamıza benzer şekilde yapılan araştırmalar incelendiğinde, medeni durumunu evli olarak belirtenlerin ölçeğin tüm alt boyut puan ortalamalarının daha düşük olduğu ve diyabet yüklerini daha az hissettikleri belirlenmiştir $(21,22)$. Diyabetli bireylerin hastalığa uyumlarının ve aile destek düzeylerinin değerlendirildiği bir çalışmada da, evli diyabetlilerin hastalığa uyumlarının anlamlı derecede yüksek olduğu saptanmıştır (34). Bu sonuçlar, bekâr ya da dul diyabetlilerin hastalıkla baş ederken tek başına kald1ğını, bununla birlikte evli olmanın ise çoğu bireye düzen, sorumluluk ve sosyal destek kazandırırken bekâr hastalarda bu kazancın eksikliğinin hastalık yükünü olumsuz yönde etkilediğini düşündürmektedir. Çalışma sonucumuzdan farklı olarak benzer şekilde yapılan bir çalışmada ise medeni durumun hastaların diyabet yükü üzerinde etkili olmadığg tespit edilmiştir (23).

Diyabet tanı süresinin artması ile birlikte diyabet nedenli gelişebilecek komplikasyonlarında artacağı ve beraberinde diyabet yükünün de arttığı yapılan çalışmalarda bildirilmiş olup (35-37) çalışmamızda da benzer sonuç bulunmuştur. Çalışmamızda hastaların diyabet süreleri ile diyabet yükleri arasındaki fark istatistiksel olarak anlamlı bulunmuştur $(p<0,001)$. "15 yıl ve üzeri” süredir diyabeti olanların diyabet yükü puan ortalamasının anlamlı derecede yüksek olduğu tespit edilmiştir. Benzer şekilde yapılan Savsar'ın çalışmasında da diyabet tanı süresi arttıkça diyabetli bireylerin diyabet yükü ölçeği toplam puanının arttığı belirlenmiştir (22). 
Diyabetin kişiye ve topluma olan yükünü azaltmak için hastalığın olabildiğince erken dönemde tanınması ve kişinin en uygun şekilde tedavi edilmesi gerekmektedir. Çalışmamızda hastalarda diyabet yanında başka bir kronik hastalığa sahip olan, bu hastalıklardan dolayı ilaç kullanan ve bu ilaçları birinin yardımı ile alabilen hastaların diyabet yükünün arttığı ve bu artışın da istatistiksel olarak anlamlı olduğu belirlenmiştir $(\mathrm{p}<0,001)$. Çalışmamıza paralel olarak Mustafova'ın çalışmasında diyabet ve diğer kronik hastalıkları nedeniyle kullandığı ilaçlarını birinin yardımı ile alan hastalarda diyabet yükünün daha yüksek olduğu belirlenmiş olup (23), bir başka çalışmada da benzer sonuç bildirilmiştir (22).

Tip 2 diyabet tedavisinin en önemli bileşenlerinden birinin düzenli fiziksel aktivite olduğu, oluşabilecek komplikasyonların önlenmesinde ve metabolik kontrolün sağlanmasında oldukça etkili olduğu bildirilmiştir $(6,7)$. Çalışmamıza katılan bireylerin büyük çoğunluğunun (\%81) düzenli egzersiz yapmadıkları tespit edilmiş, bu hasta grubunda ölçeğin bütün alt boyutları ve toplam puan ortalamalarının anlamlı düzeyde daha yüksek olduğu belirlenmiştir. Bu durum egzersiz yapan diyabetli hastalarm diyabetin kontrolünde egzersizin rolünü bildiği ve bunu hayata geçirdiği; hastalığı kabul ederek, duruma uyum sağladığı bu nedenle de algıladıkları yükün az olduğu şeklinde açılanabilir. Çalışma bulgumuza benzer şekilde yapılan bir çalışmada da düzenli egzersiz yapan hastalarda diyabet yükünün azaldığg 1 belirlenmiştir (23).

Her geçen gün sayısı giderek artan diyabetli bireylerin, yaşamlarını sağlıklı ve sorunsuz bir şekilde sürdürebilmesi için yeterli bilgi ve beceriye sahip olması gerekir $(6,7)$. Bu nedenle, diyabetli bireylerin mutlaka diyabet tedavisinin temel taşı olduğu bildirilen diyabet eğitimini alması önerilmektedir. Ancak diyabetli bireylerin yarısından daha azının diyabet eğitim programlarına ulaşabildiği bildirilmektedir (6). Çalışmamızda da diyabetle ilgili bilgi ve eğitime gereksinim duyan hastaların ölçeğin tüm alt boyut ve toplam puan ortalamasının anlamlı düzeyde yüksek olduğu tespit edilmiştir. Benzer şekilde yapılan bir çalışmada diyabet ile ilgili bilgiye gereksinim duyan hastaların ölçeğin semptom yükü alt boyut puan ortalamasının anlamlı düzeyde yüksek olduğu saptanmıştır (22). Mollaoğlu ve ark.nın çalışmasında da diyabet eğitiminin önemi vurgulanmış ve eğitim alan hastalarda diyabete ilişkin olumlu tutum geliştiği belirlenmiştir (38).

$\mathrm{Bu}$ çalışma, Zonguldak ilinde yaşayan yaşlı tip 2 diyabetli bireylerin diyabet yüklerinin incelenmesi amaciyla yapılmış olup, çalışmaya katılan yaşlı diyabetlilerin diyabete ilişkin hastalık yüklerinin orta düzeyde olduğu belir- lenmiştir. Çalışma sonuçları dikkate alındığında, hastaların yaş ve tanı süresi arttıkça gelişebilecek ek hastalıkların ve komplikasyonların kontrol altına alınması ile, hastaların düzenli doktor kontrolüne gitmelerinin ve düzenli egzersiz yapmalarının sağlanması ile yaşlı tip 2 diyabetli bireylerin diyabet yükünün azaltılabileceği düşünülmektedir. Ayrıca çalışmada yaşlı diyabetlilerin bilgi ve eğitime gereksinim duyduğu belirlenmiştir. Bu gereksinimin giderilebilmesi için düzenli aralıklarla eğitim programları oluşturulmalı, daha fazla diyabetli bireylerin bir arada bulunabileceği diyabet okulları açılmalı ve bunların duyurularak katılımları sağlanmalıdır. Ayrıca ihtiyaç duyduğunda hangi kurumlara başvurup bilgi alabileceği diyabetli bireylere bildirilmeli ve buralardan yararlanmaları sağlanmalıdır.

\section{Etik Kurul Onayı}

Zonguldak Bülent Ecevit Üniversitesi İnsan Araştırmaları Etik Kurulu'ndan 08.01.2020/710 tarih ve protokol numarası ile gerekli etik kurul onayı alınmıştır.

\section{Çıkar Çatışması}

Yazarların beyan edecek herhangi bir çıkar çatışmaları yoktur.

\section{Finansal Destek}

$\mathrm{Bu}$ çalışmanın yapılabilmesi için herhangi bir finansal destek alınmamıştır.

\section{Yazarların Makaleye Katkı Beyanı}

Çalışma konsepti/Tasarımı: Türkan Akyol Güner, Taner Bayraktaroğlu, Müge Seval. Veri toplama: Türkan Akyol Güner. Veri analizi ve yorumlama: Türkan Akyol Güner, Taner Bayraktaroğlu. Yazı taslağı: Türkan Akyol Güner, Taner Bayraktaroğlu. İçeriğin eleştirel incelenmesi: Türkan Akyol Güner, Taner Bayraktaroğlu. Son onay ve sorumluluk: Türkan Akyol Güner, Taner Bayraktaroğlu, Müge Seval.

Hakem Değerlendirmesi

Hakemlerin değerlendirmeleri sonrası yayınlanmaya uygun bulunmuştur.

\section{KAYNAKLAR}

1. World report on ageing and health. World Health Organization 2019. (Erişim Tarihi: 10.03.2020, https://www.who.int/newsroom/fact-sheets/detail/ageing-and-health).

2. Akın G. Yaşlılık. In: Her yönüyle yaşlılık. Ankara, Palme Yayıncilık, 2006, s.1-9.

3. Türkiye İstatistik Kurumu (TÜİK),Adrese Dayalı Nüfus Kayıt Sistemi 2019 Sonuçları. (Erişim Tarihi: 20.03.2020, http://tuik. gov.tr/PreTablo.do?alt_id=1047).

4. Kutsal Y.G. Yaşlanan dünyanın yaşlanan insanları. In: Yaşlılıkta kaliteli yaşam, Kutsal Y.G. Ed. Hacettepe Üniversitesi Geriatrik Bilimler Araştırma ve Uygulama Merkezi, 2002. 
5. United Nations, New York, Department of economic and social affairs, World population ageing 2013 United Nations Publication ST/SEA/SER.A/348.

6. International Diabetes Federation (IDF) Diabetes Atlas. 9th ed. (2019). (Erişim Tarihi: 20.02.2020, https://www.diabetesatlas. $\operatorname{org} /)$.

7. Diabetes mellitus ve komplikasyonlarının tanı, tedavi ve izlem kılavuzu, 2019. (Erişim Tarihi: 21.02.2020, http://temd.org. tr/admin/uploads/tbl_kilavuz/20190819095854-2019tbl_ kilavuzb48da47363.pdf).

8. International Diabetes Federation (IDF) Diabetes Atlas, 1th ed. (2000). Erişim Tarihi: 10.02.2020, http://www.idf.org/ webdata/docs/Diabetes\%20Atlas\%20Executive\%20Summary. pdf).

9. Satman I, Omer B, Tutuncu Y, Kalaca S, Gedik S, Dinccag N, Karsidag K, Genc S, Telci A, Canbaz B,Turker F, Yilmaz T, Cakir B, Tuomilehto J. TURDEP-II Study Group. Twelveyear trends in the prevalence and risk factors of diabetes and prediabetes in Turkish adults. Eur J Epidemiol. 2013;28(2):169180.

10. Buzlu S. Diyabetin psikososyal yönü. In: Erdoğan S. (Edt), Diyabet Hemşireliği Temel Bilgiler. İstanbul, Yüce Yayın, 2002; s.195-205.

11. Bayraktar M. Ulusal Hastalık Yükünde Diyabetin Önemi, Ulusal Hastalık Yükü Çalışması Sonuçları ve Çözüm Önerileri, 2017. (Erişim Tarihi: 10.03.2020, http://www.tip.hacettepe. edu.tr/ekler/pdf/ulusal_program.pdf).

12. Sinclair AJ. Aging and diabetes mellitus. In: Defronzo RA, Ferrannini E, Keen H, Zimmet P. International Textbook of Diabetes Mellitus, 3th. England, John Wiley\&Sons Ltd., 2004, p.1579-97.

13. Miura H, Satake S, Fujisawa M, et al. Comprehensive geriatric assessment for management of the elderly with diabetes mellitus. Nihon Rinsho. 2006;64(1):106-111.

14. Araki A, Ito H. Development of elderly diabetes burden scale for elderly patients with diabetes mellitus. Geriatrics\&Gerontology International. 2003;3:212-224.

15. Fagot-Campagna A, Bourdel-Marchasson I, Simon D. Burden of diabetes in an aging population: Prevalence, incidence, mortality, characteristics and quality of care. Diabetes Metab. 2005;31(5):35-52.

16. T.C. Sağlık Bakanlığı Türkiye Halk Sağlığı Kurumu. Türkiye Diyabet Programı; 2015-2020. Erişim Tarihi: 15.12.2019, https://www.extranet.who.int/ncdccs/Data/TUR_D1_T\%C3 \%BCrkiye\%20Diyabet\%20Program\%C4\%B1\%202015-2020. pdf).

17. Zonguldak Nüfus Yoğunluğu, 2019. (Erişim Tarihi: 10.01.2020, http://www.zonguldak.gov.tr/ilcelerimiz).

18. Yazıcıoğlu Y, Erdoğan S. Spss uygulamalı bilimsel araştırma yöntemleri. Ankara, Detay Yayıncılık, 2004.

19. Folstein MF, Folstein SE, McHugh PR. Mini-Mental state: A practical method for grading the cognitive state of patients for the clinician. J Psychiatr Res. 1975;12(3):189-198.
20. Güngen C, Ertan T, Eker E, Yaşar R, Engin F. Standardize mini mental test'in Türk toplumunda hafif demans tanısında geçerlik ve güvenilirliği. Türk Psikiyatri Dergisi. 2002; 13(4):273-281.

21. Ovayolu Ö, Ovayolu N, Doğru A, Özkaya M. The challenge of diabetes in the elderly and affecting factors: A Turkish study. Holist Nurs Pract. 2015;29(2):272-279.

22. Savsar A. Diyabetik ayağı olan yaşlı hastaların sağlık inançlarının diyabet yükü üzerine etkisi, Erciyes Üniversitesi Sağlık Bilimleri Enstitüsü Hemşirelik Anabilim Dalı, Yüksek Lisans Tezi, Kayseri, 2017. (Erişim: https://tez.yok.gov.tr/ UlusalTezMerkezi/tezSorguSonucYeni.jsp).

23. Mustafova Z. Yaşlı diyabetli hastalarda diyabet yükü ve hastalığı kabul arasındaki ilişkinin değerlendirilmesi, Hacettepe Üniversitesi Sağlık Bilimleri Enstitüsü, İç Hastalıkları Hemşireliği Programı Yüksek Lisans Tezi, 2015. (Erişim: https://tez.yok.gov.tr/UlusalTezMerkezi/tezSorguSonucYeni. jsp).

24. Usta YY, Esen A. A study of the validity and reliability of the eldery diabetes burden scale for the Turkish society. Türk Geriatri Dergisi. 2012;15(1):61-67.

25. Dünya Sağlık Örgütü (2010). Bulaşıcı Olmayan Hastalıklara İlişkin Küresel Durum Raporu. (Erişim Tarihi: 20.03.2020, http://beslenme.gov.tr/content/files/home/kuresel_durum_ raporu.pdf).

26. Naeem Z. Burden of diabetes mellitus in Saudi Arabia. Int J Health Sci (Qassim). 2015;9(3):5-6.

27. Charvat $\mathrm{H}$, Goto A, Goto M, Inoue M, Heianza Y, Arase $\mathrm{Y}$, et al. Impact of population aging on trends in diabetes prevalence: A meta-regression analysis of 160,000 Japanese adults. J Diabetes Investig. 2015;6(5):533-542.

28. WHO (1972) Psychogeriatric, report of a WHO Scientific Group, Technical Reports Series 507, Geneva. Cited in Davise AM. Epidemiology 185;14(1):9-21.

29. WHO (1984) The uses of epidemiology in the study of the elderly. WHO, Technical Reports Series 706, Geneva:8-9.

30. Trief PM, Wade MJ, Pine D,Weinstock R. Acomprasion of health-related quality of life of elderly and younger insulintrated adults with diabetes. Age Ageing. 2003;32(6):613-618.

31. Terkeş N. Tip 2 Diyabetli bireylerde diyabet belirtileri kontrol listesi ölçeği'nin geçerlik ve güvenirlik çalışması, Yüksek Lisans Tezi, Akdeniz Üniversitesi Sağlık Bilimleri Enstitüsü, Antalya, 2012.

32. Can Çiçek S, Yıldırım Usta Y, Doğanyiğit D, Ankaralı H. Diabetes burden and related factors in the elderly with diabetes. Antalya Turkey: 1st International Internal Medicine Nursing Congress; 25-27 November, 2018.

33. Selvin E, Coresh J, Brancati FL. The burden and treatment of diabetes in elderly individuals in the U.S. Diabetes Care 2006;29(11):2415-2419.

34. Akın S. Diyabetli hastalarda uyumun ve aile destek düzeylerinin belirlenmesi. Yüksek Lisans Tezi, İstanbul Bilim Üniversitesi Sağlık Bilimleri Enstitüsü, İstanbul, 2011. 
35. Kasteleyn, M.J. et al. Diabetes-related distress over the course of illness: results from the diacourse study. (Erişim Tarihi: 17.03.2020, http://www.ncbi.nlm.nih.gov/ pubmed/?term=Diabetes-related +distress+over+the+course+ of+illness\%3A+results+from+the+Diacourse+study), 2015).

36. Altunoğlu EG, Sarı Z, Erdenen F, Müderrisoğlu C, Ülgen E, Sarı M. Tip 2 diabetes mellitus'lu hastalarda diyabet süresi ve HbA1c düzeyleri ile depresyon, anksiyete ve yeti yitimi arasındaki ilişki. Istanbul Med J. 2012;13(3):115-119.
37. Gafvels C,Wandell PE. Coping strategies in men and women with type 2 diabetes in Swedish Primary Care. Diabetes Res Clin Pract. 2006;71:280-289.

38. Mollaoğlu M, Özkan Tuncay F, Fertelli T, Çelik Z. Diyabet eğitim programının diyabetik hastaların tutumları üzerine etkisi. Furat Sağlık Hizmetleri Dergisi. 2010;5(15):95-105. 